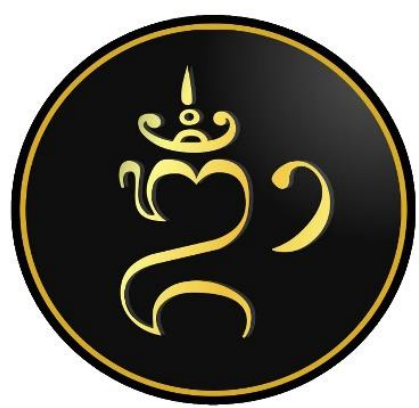

E-ISSN: $2722-8576$

E-ISSN: 1978-7014

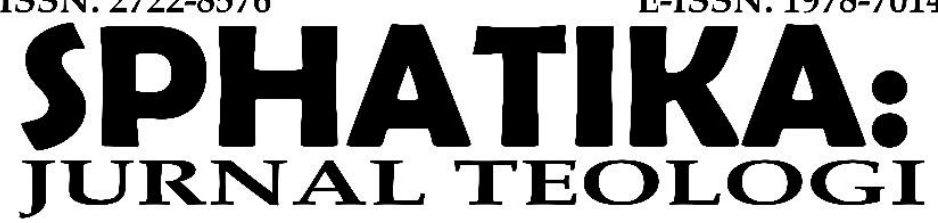

UNIVERSITAS HINDU NEGERI

I GUSTI BAGUS SUGRIWA DENPASAR

VOLUME 12 NOMOR 1, MARET 2021

\title{
FORMULASI TEOLOGI KERJA DAN HUBUNGANNYA DENGAN REINKARNASI DALAM TEKS BHAGAVAD GĪTĀ
}

\author{
Prasanthy Devi Maheswari ${ }^{1}$ \\ 1 Universitas Hindu Negeri I Gusti Bagus Sugriwa Denpasar \\ ${ }^{1}$ prasanthydevimaheswari@gmail.com
}

\section{Keywords:}

Bhagavad Gìtā;

reincarnation;

theology of work

\section{Kata kunci:}

Bhagavad Gìtā;

reinkarnasi;

teologi kerja
Abstract (Justify, Italic and Bold, book antiqua 11)

Every action will produce a result (phala) which leads to two motives, namely attachment and freedom. Humans in their lives can choose which goals they will achieve. Do they choose to be bound by the results of each work or otherwise surrender all the results of their work as an offering to God. Work done as an offering to God will achieve liberation and joy, on the other hand, work done with the motive of hoping for the result (phala) as a reward will increase the feeling of attachment and sorrow. Therefore, people who want to find happiness and true self must place their goals in work that are entirely an offering to God. This is what is meant by Theology of Work or the term in Bhagavad Gita is called Karma Yoga, which is the highest knowledge of a main Principle of Work. The realization of an understanding of the real concept about Theologi of Work can help humans break the chain of reincarnation (punarbhava) by presenting God in every work activity, whether in the form of actions, speech or thoughts.

Abstrak (rata kanan kiri, cetak miring dan tebal, book antiqua 11)

Setiap perbuatan akan mendatangkan hasil (phala) yang berujung pada dua motif yaitu keterikatan dan kebebasan. Manusia dalam hidupnya dapat memilih tujuan mana yang akan mereka capai. Apakah mereka memilih terikat dengan hasil pada setiap kerjanya atau sebaliknya menyerahkan segala hasil dari kerjanya sebagai bentuk persembahan kepada Tuhan. Kerja yang dilakukan sebagai sebuah persembahan kepada Tuhan akan mencapai pembebasan dan sukacita, sebaliknya kerja yang dilakukan dengan motif berharap pada hasil (phala) sebagai sebuah imbalan akan semakin menumbuhkan rasa keterikatan dan kesedihan. Oleh karena itu, orang yang ingin menemukan kebahagiaan dan diri sejati harus menempatkan 
tujuannya pada kegiatan kerja yang seutuhnya menjadi persembahan kepada Tuhan. Inilah yang dimaksud dengan Teologi Kerja atau istilah dalam Bhagavad Gìtā disebut sebagai Karma Yoga, yaitu pengetahuan tertinggi tentang sebuah Prinsip sebuah Kerja yang utama. Terwujudnya pemahaman tentang konsep yang seseungguhnya dari teologi kerja ini dapat membantu manusia dalam memutuskan rantai reinkarnasi (punarbhava) dengan cara menghadirkan Tuhan dalam setiap aktivitas kerja, baik dalam bentuk tindakan, ucapan maupun pikiran.

\section{PENDAHULUAN}

Manusia tersusun oleh dua aspek yaitu aspek fisik dan rohani. Kedua aspek tersebut membutuhkan nutrisi untuk dapat tumbuh dan berkembang dengan baik. Ketika aspek fisik membutuhkan makanan, begitu pula aspek rohani, ia juga membutuhkan nutrisi yaitu dengan nutrisi pemahaman yang benar tentang hidup dan kehidupan. Bagaimana sang Jiwa yang ada di dalam diri seseorang dapat mencapai sebuah kesadaran, bahwa ia bukanlah badan tetapi yang sesungguhnya ada ialah atma yang merupakan jatidiri manusia yang sesungguhnya. Akan tetapi seseorang tetap harus menjaga kesehatan jasmaninya sebelum ia mendapatkan kondisi jiwa yang sehat. Rohani manusia juga membutuhkan nutrisi yaitu dengan cara mengetahui tentang ajaran agama, yang sering disebut dengan dunia spiritual.

Kebutuhan spiritual dapat terpenuhi dengan cara mengetahui tentang teologi. Dister (2007:17) menyatakan bahwa: Teologi adalah pengetahuan adikodrati yang metodis, sistematis dan kohern tentang apa yang dinamai sebagai wahyu Allah atau berkaitan dengan wahyu itu. Teologi harus digolongkan dalam kegiatan intelektual manusia yang disebut "tahu" dan "mengetahui". Pengetahuan ini tidak terbatas pada pengetahuan indriawi dan logika seperti halnya ilmu empiris, tetapi ilmu ini melampaui panca indira, oleh sebab itu untuk mengatahuinya membutuhkan pemahaman yang melampaui ilmu pengetahuan empiris.

Konsep Teologi-kerja telah dijelaskan diberbagai kitab suci Hindu. Teologi-kerja atau aktivitas kerja dalam agama Hindu ini juga dapat diartikan sebagai karma. Yang mana secara etimologi katanya, kata karma berasal dari bahasa Sansekerta dengan akar kata $k r$ yang berarti kerja, tindakan atau berbuat. Sesuai kemampuan yang dimiliki oleh masing-masing manusia, Hindu memberikan konsep Catur Marga, yaitu empat jalan untuk memuja Tuhan. Berdasarkan ajaran Catur Marga maka apa yang disebut sebagai 
teologi-kerja dalam konteks ini adalah suatu pengetahuan tentang kerja yang dilandasi dengan dasar melakukan persembahan kepada Tuhan sesuai dengan petunjuk kitab suci. Teologi-kerja ini juga dapat dikategorikan sebagai bentuk dari wujud rasa syukur manusia kepada Tuhan yang dilakukan dengan cara melakukan kerja. Aktivitas kerja harus dilandaskan dengan wujud dari persembahan kepada Tuhan. Konsep ini dalam Bhagavad Gìtā dimaksud dengan karma yoga, yaitu rahasia tertinggi dari prinsip kerja yang membantu manusia mencapai kebahagiaan hingga kelepasan.

Berdasarkan uraian-uraian di atas dapat ditarik suatu formulasi Teologi Kerja yaitu suatu batasan yang memberikan penjelasan tentang kerja yang didasari oleh rasa bhakti kepada Tuhan. Dapat juga diartikan bahwa Teoogi Kerja adalah segala aktivitas yang dipandang sebagai persembahan kepada Tuhan. Konsep aktivitas kerja ini memberikan pemahaman bahwa setiap karma atau perbuatan pasti mendatangkan phala (hasil). Karma yang terpaku pada phala akan mengakibatkan manusia terjerumus pada ikatan duniawi. Hal ini dapat mengakibatkan manusia tidak akan mencapai kelepasan. Oleh karena itu, sangatlah penting untuk dipahami konsep karma yang tidak terikat akan phala sebagai aplikasi dari teologi kerja. Dengan menjadikan aktivitas kerja sebagai jalan menuju Tuhan, diharapkan dapat memutus rangkaian kelahiran kembali atau sering dikenal dengan istilah reinkarnasi (punarbhawa).

\section{METODE}

Jenis penelitian yang digunakan yaitu penelitian kualitatif dengan metode library research. Jenis data dalam penelitian ini adalah data kualitatif yang diperoleh melalui dua sumber data, yaitu data primer dan data sekunder. Teknik pengumpulan data dilakukan dengan cara studi pustaka, studi dokumen dan penelusuran data online. Setelah itu, data yang telah terkumpul dianalisis menggunakan tiga tahap yaitu reduksi data, klasifikasi data, dan display data. Kemudian pada tahap akhir yaitu hasil analisis data disajikan menggunakan teknik deskriptif.

\section{PEMBAHASAN}

\subsection{Formulasi Teologi Kerja}

Setiap orang harus berusaha untuk menemukan Tuhan dalam segala hal, dan juga harus menemukan sendiri cara berdoa yang pas untuk diri masing-masing yang sesuai dengan kondisi atau profesinya. Semua hendaknya berusaha untuk menemukan Tuhan dalam semua pekerjaannya. Caranya adalah setiap orang harus melangkah maju di jalan 
jiwa atau roh (atma), dan membiasakan diri untuk merasakan kehadiran jiwa, roh (atma) dalam segala perbuatan dan juga dalam segala perbuatan serta segala hal yang dijumpainya.

Sathya Narayana menyatakan

"...the work should be undertaken earnestly without expecting the results. The work should be undertaken as a sacred obligation (svadharma). This sentence poses the essence of the secret of work. Working conscientiously without expecting the outcome isthe work leading people to attain the highest happiness in the work conversely, working with the reward motive will cause people to experience the feelings of joy and sorrow..." (Donder, 2012:92).

Penjelasan diatas menyatakan bahwa kegiatan kerja yang dilakukan atas dasar kewajiban suci dan dilakukan secara sungguh-sungguh tanpa mengharapkan hasilnya, inilah kerja yang menyebabkan seseorang mencapai kebahagiaan tertinggi hingga seseorang terlepas dari rasa suka dan duka. Dengan memahami kegiatan kerja itu merupakan persembahan kepada Tuhan dan hasilnyapun dipersembahkan kepada Tuhan, maka pekerjaan itu akan menjadi sesuatu yang mulia.

Karma tidak hanya pada apa yang terlihat pada perilaku badaniah saja, namun karma juga meliputi pikiran dan ucapan. Ketiganya mempunyai peranan yang samasama penting, karma dalam berpikir tidak tampak apabila tidak disertai dengan ucapan, demikian pula tidak ada karma tindakan apabila tidak melalui karma berpikir terlebih dahulu. Bila ketiga aspek tersebut terjaga, terkendali atau terkontrol dengan baik pasti karma atau perbuatan yang dilakukan akan membawa akibat, buah (phala) yang baik pula (Jendra, 2004: 1-9).

Perbuatan yang dilakukan secara terus menerus akan membentuk sebuah karakter pada seseorang, oleh sebab itu manusia hendaknya membiasakan diri selalu melakukan kebaikan. Selain itu, karma phala merupakan hasil yang akan dinikmati oleh siapa yang melakukannya dan tidak akan bisa dilimpahkan kepada orang lain. Jadi, ketika seseorang ingin memperbaiki kehidupannya menjadi lebih baik, maka seseorang harus mulai membiasakan diri dengan mulai berkarma baik. Orang yang memahami secara baik dan benar tentang hukum kerja (Karma Phala), maka ia akan selalu seimbang dalam segala keadaan dan tidak terpengaruh oleh keadaan suka maupun duka. Hukum karma phala sesuai Manu Dharmaçastra dan Bhagavad Gìtā, menjelaskan bahwa apapun yang ditanam, maka itu pula yang akan dipetik. Selain itu, Bhagavad Gìtā menyarankan kepada manusia untuk melakukan kerja tanpa motif pahala, sebagaimana uraian beberapa sloka berikut ini: 
Karmaṇy evadhikāras te mā phaleșu kadācana, mā karma-phala-hetur bhūr mā te sañngo 'stv akarmaṇni

(Bhagavad Gìtā II.47)

Tugasmu kini hanyalah berbuat dan jangan sekali-kali mengharapkan akan hasilnya; jangan sekali-kali hasil yang menjadi motifmu ataupun sama sekali terikat dengan tanpa gerak. (Maswinara, 1999 :144)

yoga-sthạ kuru karmāṇi sañgam் tyaktoā dhanañjaya, siddhy-asiddhyoh samo bhütvā samatvam yoga ucyate

(Bhagavad Gìtā II.48)

Mantapkanlah dalam Yoga dan lakukanlah kegiatanmu, wahai Dhanañjaya (Arjuna), lepaskan keterikatan dan tetap teguh baik dalam keberhasilan maupun kegagalan, karena ketenangan pikiran itu disebut sebagai Yoga. (Maswinara, 1999:145)

Śri Krșṇa menyatakan dalam sloka di atas untuk mencapai sebuah disiplin yoga maka seseorang seharusnya tidak fokus pada hasil dari apa yang diperbuat, namun manusia hendaknya hanya fokus pada kerja itu sendiri. Manusia tidak terpengaruh apakah kerja yang dilakukan akan berhasil ataupun gagal, namun yang lebih utama yaitu manusia tetap teguh melaksanakan kerja. Manusia yang telah tegur dengan dirinya maka ia dikategorikan sebagai seseorang yang telah mencapai ketenangan. Tingkat ketenangan ini sama dengan pencapaian tujuan yoga.

Bhawuk (2011:117) menyatakan Bhagavad Gìtā merekomendasikan praktik karma yoga, atau jalan kerja, sebagai intervensi untuk menghindari ketidakbahagiaan akibat mengejar keinginan. Ini dilakukan melalui refleksi diri dan kontemplasi. Dengan terusmenerus merefleksikan keinginan kita dan konsekuensinya, kita dapat mengembangkan kesadaran tentang bagaimana pikiran kita ditarik ke elemen dunia. Kita dapat perlahan-lahan melepaskan diri dari keinginan dengan bernegosiasi dengan batin kita dan dengan mengenali kesia-siaan siklus pemenuhan dan kemunculan kembali yang tak pernah terpuaskan. Oleh karena itu, refleksi diri dan kontemplasi diperlukan agar kita dapat mengikuti jalan Karma yoga, atau jalan spiritual apa pun, yang dapat membantu kita menjauh dari belenggu keinginan. Bhagavad Gìtā menyatakan lebih lanjut bahwa melepaskan hasil dari kerja akan membawa pada kedamaian pikiran. Keadaan pikiran yang damai ini dijelaskan dalam Bhagavad Gìtā sebagai tataran sthitaprajna atau keadaan ketenangan batin di mana seseorang melampaui kognisi, emosi, dan perilaku, bahkan melampaui kebahagiaan - menuju kebahagiaan sejati.

Donder (2012:108) merumuskan konsep teologi kerja sebagai persembahan kepada Tuhan dan menyerahkan semua hasil kerja sebagai yajña atau pengorbanan suci kepada Tuhan. Dalam hal ini, kerja yang dimaksud yaitu perbuatan baik yang 
merupakan wujud dari manifestasi ketuhanan yang terjadi dalam diri seseorang. Selain itu, Donder juga menyatakan bahwa puncak dari kemanusiaan adalah ketika manusia telah berhasil melaksanakan konsep dari teologi kerja ini sebagai bentuk aplikasi dari Teologi Panteisme dan konsep Vasudhaiva Kuțumbakam. Jadi, seluruh kegiatan kerja (karma) ditujukan kepada Tuhan yang meliputi seluruh alam semesta beserta isinya atau dalam kata lain melihat segalanya adalah wujud Tuhan, berbuat baik pada sesama manusia, pada tumbuhan, hewan dan seluruh ciptaan-Nya dan menganggap bahwa seluruh dunia dan semua makhluk adalah satu keluarga. Inilah teologi kerja yang dapat membawa seseorang mencapai kesadaran teologis.

Berdasarkan uraian-uraian di atas dapat dibentuk suatu formulasi Teologi Kerja yaitu suatu batasan yang memberikan penjelasan tentang kerja yang didasari oleh rasa bhakti kepada Tuhan. Atau dengan kata lain, Teologi Kerja adalah segala aktivitas kerja yang dipandang sebagai persembahan kepada Tuhan dan tanpa mengharapkan hasil. Kata "kerja" sesungguhnya berasal dari Bahasa Sansekerta dengan akar kata $k r$ yang kemudian menjadi bahasa Indonesia kriya, karya dan kerja. Kata “kerja' dalam bahasa Sanskerta sama artinya dengan karma. Dan konsep teologi kerja dalam teks Bhagavad Gìtā dikenal dengan istilah Karma Yoga.

\subsection{Teologi-Kerja sebagai Konsep Karma Yoga dalam Bhagavad Gītā}

Uraian tentang Teologi-Kerja dalam ajaran Hindu dapat dibaca dalam sloka-sloka Bhagavad Gītā, sebab secara historis, pengajaran Bhagavad Gìtā penuh dengan hal teologikerja yang disampaikan oleh Śri Kṛṣna. Inti sari ajaran Bhagavad Gìtā yaitu dharma-mama, yang mana berarti seseorang dianjurkan agar melakukan swadharma-nya sendiri dengan sungguh-sungguh sebagai korban suci atau persembahan kepada Tuhan.

Selain sadar akan kewajiban sendiri, seorang manusia hendaknya terbebas dari motif hasil dari kerja yang dilakukan, karena ketika seseorang masih terikat oleh phala, maka ia juga secara otomatis terikat pada suka-duka. Sebab, ketika hasil yang diterima tidak sesuai dengan apa yang diharapkan, maka kedukaan pun akan menghampiri. Oleh karena itu, dengan pemahaman yang benar terhadap hukum kerja (Karma Phala), maka ia akan mampu melepaskan ikatannya terhadap hasil (Bhagavad Gìtā II.38). Sehingga seseorang hanya fokus pada kerja dan menyerahkan segalanya kepada Tuhan.

Penjelasan yang lebih mendalam tentang hakikat kerja sebagai persembahan kepada Tuhan dibahas dalam Bhagavad Gìtā Bab III, dengan judul Karma Yoga yang 
identik disebut dengan istilah Teologi-Kerja. Hakikat dari teologi kerja terdapat pada kutipan sloka-sloka Bhagavad Gìtā sebagai berikut:

karma-jam̉ buddhi-yuktā hi phalam tyaktvā manișinạh, janma-bandha-vinirmuktāh padaṁ gacchanty anāmayam

(Bhagavad Gìtā II.51).

Orang bijaksana yang telah menyatukan kecerdasannya (dengan yang bersifat Ilahi), dengan melepaskan hasil dari kegiatan yang dilakukannya dan terbebas dari belenggu kelahiran kembali serta mencapai keadaan yang tanpa penderitaan lagi. (Maswinara, 1999:146-147)

Sebagaimana dijelaskan pada sloka di atas, seseorang dapat terbebas dari karma dan penderitaan yaitu orang yang mampu memusatkan pikirannya kepada Tuhan (dengan pikirannya dapat mencapai kesadaran ketuhanan) dan bebas dari motif atau phala dari kerja yang dilakukan. Orang awam mungkin belum memahami hakikat hukum karma phala ini, karena itu pula mereka masih terikat oleh harapan akan hasil dari apa yang dikerjakan. Mereka masih sulit memahami "hakikat kerja", yang bebas dari motif phala. Pada dasarnya, ada dua macam jalan di dunia ini untuk menuju kepada Tuhan, sebagaimana dinyatakan pada sloka berikut:

loke 'smin dvi-vidhā nișthā purā proktā mayā'nagha, jũana-yogena sānkhyānām karma-yogena yoginām

(Bhagavad Gìtā III.3)

Wahai Anagha (Arjuna), di dunia ini sejak dahulu telah Ku-ajarkan dua macam jalan dalam kehidupan ini, yaitu: jalan pengetahuan bagi mereka yang suka melakukan perenungan dan jalan kegiatan kerja bagi mereka yang bersemangat untuk bekerja. (Maswinara, 1999:163)

Sloka di atas menjelaskan bahwa ada dua jalan yang dapat ditekuni untuk mencapai kebebaban yaitu dengan jalan pengetahuan dan jalan kerja. Tetapi, pembagian ini tidak bersifat kaku, namun salah satu jalan yang dipilih dapat ditentukan sesuai dengan kematangan spiritual yang dimiliki setiap orang. Bhagavad Gìtā memberikan penjelasan bahwa jalan kerja adalah jalan yang sama baiknya dengan jalan ilmu pengetahuan, untuk mencapai kebebasan. Karena itu kedua jalan ini tidaklah bersebrangan melainkan kedua jalan ini saling melengkapi satu dengan yang lainnya. Namun dalam hal ini, melaksanakan konsep teologi kerja juga harus ditunjang dengan pemahaman yang benar tentang apa itu esensi dari kerja itu sendiri. Sloka berikut dinyatakan bagaimana keutamaan dari sebuah kegiatan kerja. Sloka tersebut berbunyi sebagai berikut:

na karman̄ām anārambhān naișkarmiyam purușo 'snute, na ca saminyasanād eva siddhim samadhigacchati

(Bhagavad Gìtā III.4) 
Bukan dengan tidak bekerja orang mencapai kesempurnaan, atau hanya dengan penyangkalan kegiatan kerja orang mencapai kesempurnaan. (Maswinara, 1999:164)

tasmād asaktạ̣ satatä̇ kāryà் karma samācara, asakto hy ācaran karma param āpnoti pürușah.

(Bhagavad Gìtā III.19)

Oleh karena itu, tanpa keterikatan, lakukanlah selalu kegiatan kerja yang harus dilakukan, karena dengan melakukan kerja tanpa pamrih seperti itu membuat manusia mencapai tingkatan tertinggi (Maswinara, 1999:172).

Sloka di atas menjelaskan bahwa "tidak ada seorangpun yang dapat menghindari aktivitas kerja, bagaimanapun caranya. Kebebasan pun tidak akan dapat dicapai tanpa kerja, demikian juga kesempurnaanpun tidak akan tercapai apabila menghindari kegiatan kerja. Hal ini memiliki makna bahwa manusia dibelenggu oleh hukum kerja. Sebagaimana telah diuraikan sebelumnya di atas, dalam Manu Dharma Sastra juga dinyatakan bahwa ada dua motif dalam bekerja, yang pertama adalah motif keterikatan, dan yang kedua motif kebebasan. Hal yang paling utama sesungguhnya bekerja dengan motif kebebebasan. Orang-orang bijaksana berhasil mencapai kondisi naișkarmya, yaitu suatu kondisi dimana hasil dari kegiatan kerjanya tidak lagi mempengaruhi aktivitas kerjanya. Atau dengan kata lain kondisi ini merupakan kebebasan dari tugas yang telah ditentukan dan reaksi dari tugas tersebut; tindakan yang dilakukan dalam kesadaran ketuhanan yang tidak akan menimbulkan reaksi apa-apa terhadap yang melakukan kerja tersebut. Kondisi ini dapat dicapai ketika seseorang telah mencapai kesadarannya, yang telah memahami hakikat kerja dari hukum-hukum alam. Oleh karena setiap kegiatan kerja apapun itu memiliki reaksi yang bersifat alami, maka hasil kerja tersebut dapat menjadi sumber keterikatan yang baru bagi orang yang melakukan kegiatan di dunia ini. Tidak ada satu orangpun yang dapat terlepas dari hukum kerja, karena hukum alam memaksa kepada manusia dan alam untuk selalu bekerja, sebagaimana uraian sloka berikut :

na hi kașcit kṣaṇam api jātu tișthaty akarma-krt, kāryate hy avașah karma sarvah prakåti-jair gunaih

(Bhagavad Gìtā III.5).

Tak seorangpun dapat tetap tanpa melakukan kegiatan kerja walau hanya sesaat saja, karena setiap orang dibuat tak berdaya oleh kecenderungan-kecenderungan alam untuk melakukan kegiatan kerja (Maswinara, 1999:164).

niyatam kuru karma toam karma jyāyo hyakarmaṇah, șarira-yātrāpi ca te na prasiddhyed akarmaṇah

(Bhagavad Gìtā III.8). 
Lakukanlah kegiatan yang diperuntukkan bagimu, karena kegiatan kerja lebih baik dari pada tanpa kegiatan; dan memelihara kehidupan fisik sekalipun tak dapat dilakukan tanpa kegiatan kerja (Maswinara, 1999:166).

Sloka di atas begitu jelas menguraikan bahwa bekerja, bergerak, atau beraktivitas merupakan sifat alam. Sifat alami inilah dalam ajaran Hindu disebut guna, yang terdiri atas tiga macam, yaitu, sattva, rajah, tamah. Setiap ciptaan memiliki tiga sifat yang hakiki ini. Ketiga sifat ini yang membentuk sifat 'karma' ada pada setiap diri manusia. Selama menjalani kehidupan di dunia ini, seluruh ciptaan Tuhan termasuk manusia tidak dapat melepaskan dirinya dari kegiatan kerja. Karena tanpa melakukan kerja, maka kehidupan juga tidak akan berlangsung. Kehidupan itu sendirilah adalah kegiatan kerja, dan setiap kegiatan kerja itu menimbulkan akibat yang berbeda.

Bhawuk (2011:103) menyatakan, kerja adalah hal yang alami bagi manusia. Bahkan manusia didorong oleh sifat (guna) dan tidak dapat hidup bahkan hanya untuk sesaat tanpa melakukan kerja. Bhagavad Gìtā memberikan dua langkah bagaimana melakukan karma yoga (yoga melalui kerja). Yang pertama, manusia harus mengatur indera dengan menggunakan manas, dan kemudian manusia harus bekerja tanpa terikat pada apapun yang dilakukan atau dengan kata lain tidak terikat pada hasil dari kerja. Seperti halnya Śrī Krș̣na yang mengatakan kepada Arjuna pada saat berada di medan perang agar dapat bertarung dengan kesadaran spiritual, tanpa harapan apapun, tanpa ego atau rasa memiliki, dan tanpa kecemasan atau kesusahan manas. Dan, metode terakhir yaitu penyerahan secara utuh seperti Arjuna yang diminta menyerahkan segala perbuatannya kepada Śrī Kṛṣna. Dengan demikian, Bhagavad Gìtā memberikan metode untuk melaksanakan karma yoga, yang digambarkan dalam dua jalan sebagai jalan yang mengarah ke jati diri atau Atman dan bekerja tanpa kemelekatan dengan keseimbangan batin.

Bagi mereka yang telah berhasil bebas dari pengaruh guna, maka kegiatan kerjanya bukan lagi tertuju pada keperluan duniawi, melainkan kegiatan kerja itu ditujukan untuk memuliakan Tuhan. Terlebih lagi, Tuhan sendiri menciptakan alam semesta ini beserta seluruh isinya melalui korban suci (yajna). Hal ini sangat jelas diuraikan pada sloka berikut:

yajñarthāt karmano 'nyatra loko 'yam karma-bandhanah, tad-artham karma kaunteya mukta-sañgah samācara

(Bhagavad Gìtā III.9).

Kecuali kerja yang dilakukan sebagai dan untuk tujuan pengorbanan, dunia ini terbelenggu oleh kegiatan kerja. Oleh karena itu, wahai Putra Kunti (Arjuna), 
lakukanlah kegiatanmu sebagai pengorbanan itu dan jangan terikat dengan hasilnya (Maswinara, 1999:167).

Sloka di atas dengan jelas menguraikan, bahwa untuk tujuan yajña (korban suci) maka dunia ini terikat oleh hukum karma. Dalam konteks Teologi-Kerja, maka yang dimaksud dengan karma adalah segala kegiatan kerja yang dilandaskan dengan semangat pengorbanan. Inilah prinsip kerja sebagai sebuah persembahan, yang dapat disebut dengan istilah Teologi-Kerja.

\subsection{Hubungan Teologi-Kerja dengan Hukum Karma dan Reinkarnasi}

Hubungan karma dan punarbhawa sangat erat dan tidak bisa dipisahkan. Antara karma dan punarbhawa seperti dua sisi mata uang yang mana satu sisinya adalah karma dan sisi lainnya adalah punarbhawa. Hanya orang yang sudah niskama karma saja yang mampu memotong lingkaran kelahiran dan kematian (moksa). Jendra (2004:18) menguraikan untuk menjadi orang yang bersikap karma tyaga memerlukan hal berikut: (1) kasih sayang yang tinggi; (2) disiplin tinggi dalam sadhana spiritual; (3) pengabdian yang tinggi pada masyarakat; (4) bhakti yang tekun pada tuhan; (5) tidak terlekati oleh sad ripu dan sapta timira; (6) ego (ahamkara) tak ada sama sekali dan (7) tidak membenci semua makhluk (advesa sarva bhutanam).

Ketujuh faktor tersebut saling berkaitan, karena sifat dan karakter yang satu sama lain saling berhimpit. Misalnya, orang yang egonya tinggi maka rasa kasih sayangnya rendah. Begitupula jika orang yang memiliki pengabdian yang tinggi tanpa pamrih kepada masyarakat sudah pasti memiliki kasih sayang dan bhakti yang tinggi pula, serta jauh dari sad ripu dan sapta timira karena ia tidak membenci lingkungan dan sekitarnya.

Konsep kelahiran kembali dalam bahasa Sansekerta yaitu punarbhava juga biasa dikenal dengan istilah reinkarnasi merupakan salah satu bagian dari Pañca Sraddha. Konsep pokok dalam kepercayaan agama Hindu. Konsep tentang punarbhava atau kelahiran kembali ini sangat dipercayai oleh umat Hindu, sebab ajaran punarbhava ini tidak bersifat dogmatis, tetapi sangat relevan dengan logika agama, logika filsafat Hindu sehingga dapat diterima oleh nalar atau akal sehat. Oleh sebab itu konsep tentang kelahiran kembali menjadi keyakinan dan pondasi kepercayaan yang sangat kuat. Selain itu, pengetahuan biasa tidak memiliki metode secara pasti tentang bagaimana proses kelahiran manusia pada permulaannya, juga tidak dapat memperkirakan berapa banyak penjelmaan. Hanya ketika seseorang telah sampai pada level pengetahuan 
tentang kesadaran ketuhanan dan memiliki kesadaran atman, maka ia akan memahaminya.

Dalam hal ini, reinkarnasi merupakan hasil akumulasi dari perbuatan yang dilakukan selama hidup. Bisa dikatakan bahwa manusia dapat menentukan baik-buruk nasib yang ditanggungnya pada kehidupan yang selanjutnya. Ajaran ini juga memberi optimisme kepada manusia. Bahwa semua perbuatannya akan mendatangkan hasil, yang akan dinikmatinya sendiri, bukan orang lain. Menurut Hinduisme, yang bisa berinkarnasi itu bukanlah hanya jiwa manusia saja. Semua jiwa mahluk hidup memiliki kesempatan untuk berinkarnasi dengan tujuan menikmati hasil perbuatannya di masa lalu dan memperbaiki kualitas hidupnya. Bila manusia ingin mencapai kehidupan yang lebih baik maka manusia harus memulai dengan melakukan karma baik hingga mampu menempatkan setiap kerja yang dilakukan merupakan persembahan seutuhnya kepada Tuhan. Kemudian setelah itu, manusia yang mampu meniadakan kemelekatannya terhadap kehidupan dunia, maka ia akan mencapai moksa dan bersatu dengan Brahman.

Adapun proses reinkarnasi yang diyakini yaitu pada saat jiwa lahir kembali, roh yang utama tetap ada namun telah meninggalkan badan kasar (wadag) yang telah rusak akibat proses kehidupan. Karena semua yang melewati proses kelahiran makan pasti akan menghadapi proses kematian. Begitulah hukum alam (Rta) yang tidak dapat dihindari oleh siapapun. Bahkan Tuhan yang menjelma ke dunia mengambil wujud avatara pun tidak bisa menghindari hukum alam teresebut. Śri Krș̣na sebagai avatāra dalam memenuhi proses kosmos ini juga berbuat seperti layaknya manusia biasa, untuk memberikan teladan dan contoh kepada umat manusia dalam menapak jalan dan mendaki tangga spiritual. Beliau juga menunjukkan jalan yang dapat meningkatkan manusia dari sifat-sifat hewani menuju tingkatan eksistensi spiritual dengan cara memberi kita contoh-contoh kehidupan spiritual. Pernyataan tersebut terdapat dalam sloka Bhagavad Gìtā yang berbunyi sebagai berikut:

jātasya hi dhruvo mrtyur dhruvam janma mrtasya ca, tasmād aparihārye 'rthe na toam șocitum arhasi.

(Bhagavad Gìtā II.27)

Bagi seseorang yang lair, kematian sudahlah pasti dan pasti ada kelahiran bagi mereka yang mati; sehingga terhadap hal yang tak terelakkan ini, janganlah engkau berduka (Maswinara, 1999:131).

Sloka di atas menggambarkan semua yang lahir, kematian adalah pasti, tidak ada satupun hal di dunia ini yang mampu mengelaknya. Proses ini bukan untuk disesali, 
melainkan direnungkan. Proses reinkarnasi yaitu berpindahnya roh ke badan yang baru untuk menikmati hasil perbuatan yang dilakukan selama hidup hingga menghadapi kematian. Pada saat memasuki badan yang baru, roh yang utama membawa hasil perbuatan dari kehidupannya yang terdahulu, yang akan menentukan baik-buruk nasibnya kelak. Manusia hendaknya harus berusaha dengan keras untuk membebaskan diri dari hukum karma, sehingga manusia tidak mengalami punarbhawa lagi. Karena vasana karma yang menyebabkan seseorang lahir kembali ke dunia. Apabila setiap melakukan karma disertai dengan sikap dan rasa bhakti yang tulus, maka akan memunculkan sebuah kebijaksanaan dan kelak dalam punarbhawa berikutnya akan mengalami peningkatan kualitas hidup. Akan tetapi, harus diingat bahwa karma dalam kategori serba tidak baik, maka akan menyebabkan punarbhawa menurun, dalam wujud kehidupan yang lebih rendah dari yang dialami sekarang.

Hal penting yang perlu disadari yaitu bahwa garis kehidupan karma setiap orang pasti berbeda, tidak akan ada yang sama. Semuanya tergantung bagaimana orang itu memahami, menghayati dan mengamalkan ajaran agama yang diketahuinya. Kehidupan dengan berkarma itupun tidak semudah yang dikatakan. Dapat dikatakan manusia yang lahir kembali kedunia akan menjalani kehidupan dalam lautan sengsara. Namun jika manusia memahami dan meyakini bahwa kehidupan ini merupakan tempat dimana manusia itu ditempa dan diberi ujian agar menjadi yang lebih baik, mungkin manusia akan mengetahui apa yang seharusnya ia lakukan dan apa yang seharusnya ia hindari.

Sebenarnya saat yang paling kritis yaitu dimana sikap mental seseorang dalam menghadapi kematian, dimana dewa Yama akan menjemput atma dari badan wadag. Dalam kitab Bhagavad Gìtā disebutkan jika saat itu manusia terkonsentrasi pada sesuatu sebelum kematiannya, maka ia akan menjadi seperti apa yang ia pikirkan. Pernyataan tersebut terdapat dalam sloka berikut ini:

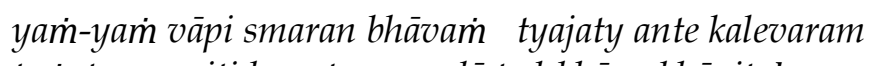
tam-tam evaiti kaunteya sadā tad-bhāva-bhāvitah

(Bhagavad Gìtā VIII.6)

Keadaan apapun yang dipikirkannya pada saat-saat terakhr ketika menanggalkan badan jasmani, kesanalah ia akan sampai, wahai Putra Kunti (Arjuna), karena ia senantiasa terserap dalam pemikiran hal ity saja (Maswinara, 1999 : 287).

Dari penjelasan sloka di atas, sesungguhnya Sang roh akan pergi pada keadaan yang telah dipolakan oleh pikiran pada saat-saat terakhir dari kehidupan. Apapun yang kita pikirkan, demikianlah nanti yang terjadi. Pemikiran-pemikiran masa lalu akan 
menentukan kelahiran yang sekarang dan pemikiran-pemikiran sekarang ini akan menentukan keberadaan masa depan kita. Oleh karena itu, sangat disarankan pada saat itu manusia berpikirlah yang baik, berpikirlah yang mulia, jika mampu konstrasikan pikiran pada Tuhan, dengan mengucapkan nama suci Tuhan, maka diyakini seseorang tersebut akan lahir kembali sebagai orang yang mulia dan jika saat itu seseorang sudah dalam jũana dan tingkat spiritual yang tinggi, hingga telah mampu mencapai kesadaran ketuhanan maka tidak menutup kemungkinan seseorang itu akan mencapai moksa.

Hubungan antara karma dan reinkarnasi terus menjadi topik perbincangan. Sampai saat ini belum ada satu pun pengetahuan modern yang mampu memberikan jawaban atas pertanyaan; mengapa atman atau roh itu dapat menjelma dan mengambil salah satu badan lain setelah kematian badan kasarnya?; Apa yang menjadi bukti bahwa reinkarnasi benar-benar ada?; apakah yang dibawa oleh atman atau roh setelah meninggalkan badan kasarnya?. Hal tersebut mengakibatkan banyak orang yang meragukan adanya reinkarnasi karena sangat sulit untuk dibuktikan. Bukti bahwa adanya reinkarnasi sesungguhnya dapat diamati dalam kehidupan sehari-hari manusia. Dalam kehidupan sehari-hari banyak didapati kenyataan di lapangan yang terjadi tidak sedikit orang-orang saling antipati dan bermusuhan satu sama lainnya tanpa ada penyebabnya. Demikian juga dalam kehidupan sehari-hari banyak dijumpai orang yang secara spontan simpati dan bahkan saling jatuh cinta tanpa alasan. Masih banyak orang yang menyatakan bahwa hal tersebut hanyalah sebuah kebetulan saja. Berbeda dengan pendapat para ilmuwan Hinduisme yang bersumber dari Veda mengatakan bahwa di dunia ini tidak ada kejadian apapun yang dapat disebut sebagai kejadian yang kebetulan. Satu lembar daun pun yang jatuh bukan sebuah kebetulan, karena dunia ini pun diciptakan bukan dari suatu kebetulan. Tetapi alam semesta diciptakan dalam satu sistem rencana Tuhan yang sangat rahasia dan maha sempurna, sehingga manusia harus berupaya untuk mengungkap rahasia itu dengan cara mempelajari Brahma Vidya secara utuh.

Segala peristiwa atau kejadian yang dialami oleh setiap orang akan terekam dalam sebuah pita kaset pikiran yang biasa juga disebut membran memori. Membran memori pikiran ini yang menyimpan semua data-data peristiwa yang dialami oleh seseorang dalam kehidupannya. Rekaman pikiran yang tersimpan dalam membran memori pikiran manusia akan terbawa kemanapun inti roh (Ananda maya kosa) itu pergi. Jika lapisan pengetahuan yang disebut dengan vijnana maya kosa merupakan pengetahuan internal tentang kesadaran yang dimiliki oleh atman itu sendiri, maka 
rekaman membran memori merupakan pengetahuan eksternal yang datang dari luar sebagai hasil tangkapan pikiran atas segala peristiwa yang terjadi selama ia menghuni badan jasmani. Hasil-hasil rekaman pikiran ini menjadi modal dasar pada kelahiran berikutnya dalam istilah umum disebut bakat bawaan.

Selain itu, yang paling luar biasa adalah bahwa hasil rekaman pita pikiran itu dapat dibawa hingga ke alam roh dan kemudian hasil rekaman itu akan menyertai ketika roh dari pikiran itu mengalami reinkarnasi ke dunia ini. Rekaman pikiran yang dibawa dari alam roh itulah yang menyebabkan adanya bakat-bakat tertentu. Bakat itu sesungguhnya bukanlah takdir atau nasib sebagaimana dilukis oleh kebanyakan orang. Bakat itu adalah hasil rekaman pikiran pada kelahiran masa lalunya. Untuk menjelaskan masalah ini para pakar Biologi menggunakan istilah sifat gen yang disebut resesif dan dominan. Kecuali alasan itu ilmuwan Biologi tidak punya alasan lain. Untuk melengkapi pengetahuan sains Biologi itulah, ajaran Hindu yang bersumber dari Veda dengan kasih Tuhan yang begitu luar biasa menguraikan pengetahuan rahasia yang pada awal-awalnya sangat dirahasiakan dan disakralkan.

Pada kelahiran berikutnya, manusia bukan hanya membawa rekaman atas semua perbuatan, melainkan juga akan membawa pengetahuan yang ia dapatkan sebelumnya, sehingga menyebabkan adanya perbedaan kecerdasan setiap orang, selain itu rekaman atas perasaan cinta dan benci juga menyertai. Ini pulalah yang menyebabkan mengapa seseorang itu dapat menjalin hubungan persahabatan yang demikian harmonis terhadap seseorang. Ini pulalah yang menyebabkan terjadinya sebuah ikatan perkawinan. Peristiwa perkawinan yang dipandang sebagai jodoh tidak lain adalah "pemenuhan janji atau pelunasan hutang masa lalu" yang biasanya juga disebut "hutang karma". Hutang karma inilah juga sebagai faktor yang menyebabkan adanya berbagai macam usia perkawinan. Ada perkawinan seseorang yang berlangsung selama hidupnya, ada juga perkawinan yang hanya seumur jagung yang kemudian berakhir dengan perceraian yang tragis.

Pengetahuan tentang rekaman dari hasil pemotretan pikiran ini akan dapat menguak sedikit tentang misteri adanya rasa cinta, adanya rasa benci yang demikian mendalam di dalam diri seseorang. Dalam kenyataan sehari-hari ada seseorang yang membenci setengah mati terhadap seseorang hanya faktor kesalahan yang sangat kecil dan kesalahan yang tidak terlalu berarti. Seolah ada dendam yang tidak mungkin saling memaafkan yang biasa juga disebut sebagai dendam turunan. Di pihak lain ada juga kenyataan bahwa seseorang itu memiliki vibrasi cinta kasih sayang yang sangat 
mendalam terhadap seseorang yang masing-masing tidak saling mengenal dalam kehidupannya sekarang. Ketika mereka bertatapan atau berpapasan saja dapat terciptanya suasana cinta kasih sayang yang mendalam tanpa sebab. Kedua kenyataan itu merupakan hubungan seseorang dengan orang lain yang saling membenci maupun yang saling mencintai. Kenyataan tersebut merupakan wujud dari produk kehidupan masa lalu. Inilah bagian kecil dari pengetahuan kesadaran sang diri yang patut dipelajari oleh setiap orang. Pengetahuan kesadaran diri ini akan membuat seseorang lebih bijak dalam menilai, menyikapi, dan menyelesaikan segala macam permasalahan dalam hidup. Orang yang memiliki pengetahuan tentang kesadaran sang diri akan memiliki sikap yang arif dengan kerangka berpikir tentang masa lalu, kini, dan akan datang.

Sebuah reinkarnasi terjadi karena hasil dari perbuatan manusia itu sendiri. Oleh sebab itu, untuk membentuk sebuah kelahiran yang lebih baik dan penuh dengan berkah, maka manusia dapat memulainya dengan melakukan karma baik selama hidupnya. Manusia tidak dapat menghindari dari hukum alam yang mengikat manusia akan kelahiran dan kematian. Oleh sebab itu manusia hanya berusaha dengan melakukan aktivitas kerja dengan berlandaskan ajaran dharma. Penjelasan tersebut terdapat pada sloka Bhagavad Gìtā yang berbunyi sebagai berikut:

\section{janma karma ca me divyam evam் yo vetti tattvatah,} tyaktvā dehà̇ punarjanma naiti mām eti so 'rjuna.

\section{(Bhagavad Gìtā IV.9)}

Ia yang mengetahui kelahiran dan kegiatan Ilahi-Ku yang sejati, tak akan menjelma kembali setelah menanggalkan badan jasmaninya dan akan datang kepada-Ku, wahai Arjuna (Maswinara, 1999:192).

Sloka di atas menyatakan bahwa siapapun yang menyadari bahwa bekerja tanpa pamrih dengan berlandaskan kebenaran (dharma) atau kata lainnya yaitu seseorang melakukan kerja yang terbebas dari phala dan menyerahkan seutuhnya kegiatan kerjanya hanya untuk persembahan kepada Tuhan, inilah yang dikatakan sebagai teologi kerja. Selain itu, jika manusia dapat sampai pada pencapaian ini maka ia akan berhasil memutuskan rantai kelahiran kembali hingga mencapai kedudukan tertinggi yang disebut jīvanmukti dan akan menyatu dengan Sang Pencipta (mokșa). Proses dari pencapaian akhir dari tujuan hidup manusia yaitu menunggal dalam 'Aku', dan oleh karena ini penjelmaan kembali ke dunia tidak akan terjadi. Konsep teologi kerja ini pula menempatkan perilaku yang baik sebagai dasar kesadaran ketuhanan. Yang artinya bahwa perbuatan baik merupakan manifestasi ketuhanan yang terjadi dalam diri 
manusia. Puncak dari kemanusiaan adalah ketika seseorang telah melakukan segala aktivitas kerja sebagai persembahan kepada Tuhan. Inilah Teologi Kerja yang dapat membawa orang sampai pada puncak kesadaran teologis yang dapat membebaskannya dari lingkaran karma dan reinkarnasi.

\section{PENUTUP}

Teologi Kerja merupakan segala bentuk aktivitas yang dikategorikan sebagai sebuah persembahan suci kepada Tuhan. Melalui konsep ini, manusia menghadirkan Tuhan dalam setiap aktivitas kerja baik berupa tindakan, ucapan maupun dalam pikiran. Aktifitas kerja dalam Bhagavad Gìtā dikenal dengan konsep Karma Yoga yaitu penyerahan diri secara utuh kepada Tuhan dengan jalan karma tanpa mengharapkan pahala. Dalam ilmu teologi, konsep ini dikenal dengan istilah teologi-kerja. Bhagavad Gìtā menyatakan apapun yang dipikir pada saat ajal tiba, maka ia akan menjadi seperti apa yang ia pikirkan pada kelahiran berikutnya. Hal tersebut menyatakan bahwa adanya keterkaitan antara karma dan renkarnasi. Jika seseorang ingin terbebas dari reinkarnasi yang buruk, maka ia harus melakukan karma baik selama hidupnya. Dan jika seseorang ingin memutuskan rantai reinkarnasi, maka ia harus menerapkan konsep teologi kerja sebagai sebuah kewajiban suci dan persembahan kepada Tuhan tanpa mengharapkan hasil, serta memusatkan pikiran pada Tuhan sebagai jalan untuk menuju pembebasan.

\section{DAFTAR PUSTAKA}

Bhawuk, Dharm P.S. 2011. Spirituality and Indian Psychology: Lessons from the BhagavadGìtā. New York: Springer.

Dister, Nico Syukur. 2007. Pengantar Teologi (Introduction to Theology). Yogyakarta, Kanisius.

Donder, I Ketut. 2010. Teologi-Pengetahuan Ilmiah tentang Tuhan-Paradigma Sanatana Dharma (Theology-Scientific Knowledge of God-Paradigm of Sanatana Dharma). Surabaya: Paramita.

Donder, I Ketut. (2012). Theology Of Work In Karma Yoga Teaching: Working As Holy Sacrifice To God. Jurnal Pangkaja IHDN Denpasar. 13(1). Hal 89-109.

Jendra, I Wayan. 2004. Karmaphala-Pedoman dan Tuntunan Moral Hidup Sejahtera, Bahagia, dan Damai. Denpasar: Deva.

Maswinara, I Wayan. 1999. Bhagavad Gītā. Surabaya: Paramita. 